\title{
36. DETERMINATION OF PALLADIUM, IRIDIUM, AND GOLD IN MAFIC AND ULTRAMAFIC ROCKS DRILLED FROM THE MID-ATLANTIC RIDGE, DSDP LEG 37
}

\author{
James H. Crocket and Yuko Teruta, McMaster University, Hamilton, Ontario, Canada
}

\section{INTRODUCTION}

Basalts and ultramafic rocks from Hole $332 \mathrm{~B}$ and Site 334 of DSDP Leg 37 have been analyzed for palladium, iridium, and gold by neutron activation. Platinum was run on all samples, but reliable values were obtained only on ultramafic rocks. The suite included one sample from each lithological unit of the two holes together with a group of 14 samples from Unit 3 of Hole 332B.

The main objective of the study was to characterize ocean-floor basalts with respect to average noble metal content and to compare these rocks with mid-ocean island basalts and basalts dredged from the sea floor. Other aims were to evaluate noble metal variability in an individual basaltic unit and to compare noble metal levels in basalts and possibly related ultramafics.

\section{ANALYTICAL METHODS}

A wet chemical neutron activation procedure modified from Crocket et al. (1968) was used. Ir was determined on a $200-\mathrm{mg}$ sample irradiated for 7 days and cooled for 14 days prior to processing. Pd-Pt-Au were determined on a separate $200-\mathrm{mg}$ sample irradiated initially for 3 days to induce $\mathrm{Pt}$ and Au activity and then, following a 6-day cooling period, re-irradiated for $12 \mathrm{hr}$ to obtain activity from $13.5 \mathrm{hr}{ }^{109} \mathrm{Pd}$. Irradiations were carried out in the McMaster Nuclear Reactor at a flux of approximately $10^{13}$ neutrons $/ \mathrm{cm}^{2} / \mathrm{sec}$. Brief notes on the counting procedure follow:

Gold-The $412 \mathrm{keV}$ gamma of 2.69 day ${ }^{198} \mathrm{Au}$ was counted with a $30 \mathrm{~cm}^{3} \mathrm{Ge}(\mathrm{Li})$ detector. Sensitivity was approximately $0.05 \mathrm{ppb}$.

Platinum-The pertinent nuclear reaction is ${ }^{198} \mathrm{Pt}(\mathrm{n}$, $\gamma)^{199} \mathrm{Pt} \quad \frac{30 \min }{\mathrm{B}-}{ }^{199} \mathrm{Au}\left(\mathrm{T}_{1} / 2=3.15\right.$ days, $\left.\gamma-158 \mathrm{KeV}\right)$. $\mathrm{Pt}$ was therefore counted in the gold spectrum but the sensitivity is low, approximately $20 \mathrm{ppb}$.

Palladium-Beta radiation from $13.5 \mathrm{hr}{ }^{109} \mathrm{Pd}$ was counted on a coincidence shielded geiger tube with a 2$\mathrm{cpm}$ background. Proof of radiochemical purity requires that the decay be followed for 3 half-lives. This criterion leads to a working sensitivity limit of 0.1 to 0.2 ppb Pd (Crocket, 1971).

Iridium-74 day ${ }^{192} \mathrm{Ir}$ was counted on both $30 \mathrm{~cm}^{3}$ $\mathrm{Ge}(\mathrm{Li})$ and $7.6 \times 7.6 \mathrm{~cm} \mathrm{NaI}(\mathrm{T} 1)$ detectors. The former count established radiochemical purity in the region of the 298,308 , and $316 \mathrm{KeV}{ }^{192} \mathrm{Ir}$ triplet, particularly the absence of $320 \mathrm{KeV} \gamma$ 's of ${ }^{51} \mathrm{Cr}$. Ir was calculated from the $\mathrm{NaI}(\mathrm{Tl})$ count which provided better counting statistics. The sensitivity limit was $0.01-p p b$ Ir.

\section{DISCUSSION OF RESULTS}

The analytical data are presented in Chapters 2 and 4 (this volume). Average noble metal contents for basalts from Hole 332B are presented in Table 1 together with averages for dredged sea-floor basalts and mid-oceanic islands where available.

\section{Hole 332B}

Gold-The average Au content of Hole 332B basalts, $3.1 \mathrm{ppb}$, differs little from the average of $3.6 \mathrm{ppb}$ obtained in a recent literature survey of gold in basaltic rocks (Crocket, 1974). Hole 332B basalts, however, are significantly higher in Au than basalts dredged from the East Pacific Rise. For the latter rocks an average of 0.64-ppb Au is calculated from the data of Gottfried et al. (1972). This difference may reflect regional variation or possibly loss of gold from dredge basalts due to submarine weathering.

Gold is apparently enriched in lithologic Unit 3 of Hole 332B. This unit averages $12.1 \mathrm{ppb}$ and contains the five highest values found in the entire hole. Unit 3 includes a subunit (No. 7) thought to be a doleritic intrusion represented by Sections 10-1, 10-3, and 11-2 of our suite. These sections are lower in gold than other Unit 3 sections and average $0.51 \mathrm{ppb}$. The very high gold values are found in samples both above and below the doleritic subunit. It is possible that they arise by diffusion of gold away from a local heat source represented by the dolerite intrusion.

Iridium-Average Ir in Hole $332 \mathrm{~B}$ is $<0.035 \mathrm{ppb}$. As 3 of the 10 lithological units sampled are below our sensitivity limit, this average is an upper limit only. The median value is also included in Table 1 . In common with dredged sea-floor basalts (see Table 1), Ir is strongly depleted in Hole 332B basalts in comparison with Ir in oceanic basalts such as Hawaii or continental basaltic rocks (Gottfried and Greenland, 1972). No correlation of Ir content with Hole 332B lithology is obvious with the data on hand.

Greenland et al. (1974) suggest that $\mathrm{Au} / \mathrm{Ir}$ ratios may be a useful index of magmatic fractionation in that $\mathrm{Au}$ seems relatively insensitive to low-pressure crystal fractionation processes in tholeiitic magma whereas Ir is partitioned into early crystallizing phases. The $\mathrm{Au} / \mathrm{Ir}$ ratio of carbonaceous chondrites, presumably representative of unfractionated material, is 0.3 (Crocket, 1971). For sea-floor basalt as represented by average $\mathrm{Au}$ and $\mathrm{Ir}$ in Hole 332B, Au/Ir $>3.1 / 0.035=89$. Thus, these rocks are characterized by a very high degree of goldiridium fractionation compared with mid-ocean island basalts such as Hawaii where $\mathrm{Au} / \mathrm{Ir}=12$ (Gottfried and Greenland, 1972).

Palladium-The Pd values of Hole 332B basalts suggest that these rocks are depleted in Pd relative to mid-ocean island basalt. The average of 11 lithological units is $<0.81 \mathrm{ppb}$ with 3 units below or near the sensitivity limit for the method. The median value, 0.39 
TABLE 1

Average Noble Metal Contents of Leg 37 Cores and Comparison with Other Basaltic Rocks

\begin{tabular}{|c|c|c|c|c|c|}
\hline Metal & Rock Type & $\begin{array}{l}\text { Average } \\
\mathrm{ppb}\end{array}$ & $\begin{array}{l}\text { Median } \\
\text { ppb }\end{array}$ & $\begin{array}{l}\text { Number of } \\
\text { Samples }\end{array}$ & Reference \\
\hline \multicolumn{6}{|l|}{ Gold } \\
\hline & $\begin{array}{l}\text { Hole } 332 \mathrm{~B} \text { basalts; unit } \\
\text { weight assigned each } \\
\text { lithological unit }{ }^{\mathrm{a}}\end{array}$ & 3.1 & & 12 & Chapter 2 (this volume) \\
\hline & $\begin{array}{l}\text { Lithological Unit } 3 \text {, } \\
\text { Hole 332B }\end{array}$ & 12.1 & & 14 & Chapter 2 (this volume) \\
\hline & $\begin{array}{l}\text { Dredge basalts mainly from } \\
\text { the East Pacific Rise, largely } \\
\text { low } \mathrm{K}_{2} \mathrm{O} \text { tholeiites. }\end{array}$ & 0.64 & & 52 & Gottfried et al. (1972) \\
\hline & $\begin{array}{l}\text { Basaltic rock, literature } \\
\text { compilation }\end{array}$ & 3.6 & & 696 & Crocket (1974) \\
\hline \multicolumn{6}{|l|}{ Iridium } \\
\hline & $\begin{array}{l}\text { Hole } 332 \mathrm{~B} \text { basalts; unit } \\
\text { weight assigned each } \\
\text { lithological unit }\end{array}$ & $<0.035$ & 0.03 & 10 & Chapter 2 (this volume) \\
\hline & $\begin{array}{l}\text { Dredge basalts, mainly from } \\
\text { the East Pacific Rise; }\end{array}$ & & $<0.05$ & 10 & Greenland et al. (1974) \\
\hline & Kilauea-Mauna Loa basalts & 0.25 & 0.25 & 10 & Greenland et al. (1974) \\
\hline \multicolumn{6}{|l|}{ Palladium } \\
\hline & $\begin{array}{l}\text { Hole } 332 \mathrm{~B} \text { basalts; unit } \\
\text { weight assigned each litho- } \\
\text { logical unit. }\end{array}$ & $<0.81$ & 0.39 & 11 & Chapter 2 (this volume) \\
\hline & $\begin{array}{l}\text { Basalts from nonorogenic } \\
\text { mid-oceanic islands (Hawaii, } \\
\text { Samoa, Tahiti, Galapagos, } \\
\text { Reunion, Azores, St. Helena, } \\
\text { Ascension) }\end{array}$ & 1.9 & & 10 & $\begin{array}{l}\text { Crocket and } \\
\text { Skippen (1966) }\end{array}$ \\
\hline
\end{tabular}

${ }^{a}$ Refers to the main rock units intersected in Hole 332B as identified and described in DSDP Leg 37, Shipboard Hole Summary, Site 332, Section D (Lithology).

$\mathrm{ppb}$, is probably a better indicator of central tendency. Both parameters indicate depletion with respect to the average of $1.9 \mathrm{ppb}$ found by Crocket and Skippen (1966) for the Pd content of mid-ocean island basalts.

Lithological Unit 3 shows consistently low Pd values. With the exception of Section 15-2, the remaining 12 samples analyzed from this unit are below or within a factor of two of the 0.1-ppb sensitivity limit.

\section{Site 334}

Samples from Site 334 include two peridotites from Cores 22 and 23 and an olivine gabbro from Core 25 . These rocks are highly enriched in Pd, Ir, and $\mathrm{Au}$ relative to the basalts from this site and from Hole 332B. Pt, which was not detected in the basalts (i.e., $<20 \mathrm{ppb}$ ) averages $35 \mathrm{ppb}$ in the two peridotites.

Activation analyses for $\mathrm{Au}$ in ultramafic rocks from ocean crust have been reported by Anoshin and Yemel'yanov (1969). They obtained an average gold content of $1.4 \mathrm{ppb}$ for 11 peridotite samples dredged from the Romanche Depression, Mid-Atlantic Ridge. The plutonic rocks from Site 334 average 16-ppb gold. In common with dredge basalts, submarine weathering may be a factor giving rise to lower gold content of the dredged rocks.

The Au/Ir ratio of Site 334 gabbros and peridotites is 28 as compared with a lower limit of 89 for the Hole 332B basalts. While these rocks are less fractionated than the basalts, their $\mathrm{Au} / \mathrm{Ir}$ ratios suggest much stronger noble metal fractionation than was observed in an alpine ultramafic pluton by Crocket and Chyi (1972) or even in Hawaiian basalts (Gottfried and Greenland, 1972) where Au/Ir ratios of 0.5 and 12, respectively, pertain.

\section{REFERENCES}

Anoshin, G.N. and Yemel'yanov, Ye.M., 1969. Gold in igneous rocks of the Atlantic Ocean as determined by radioactivation analysis: Doklady Acad. Sci. USSR, Earth Sci. Sect., v. 189 , p. 222-224.

Crocket, J.H., 1971. Neutron activation analysis for noble metals in geochemistry. In Brunfelt, A.O. and Steinnes, E. (Eds.), Proc. NATO advanced study institute: activation analysis in geochemistry and cosmochemistry: Oslo (Universitets-forlaget), p. 339-351.

, 1974. Gold. In Wedepohl, K.H. (Ed.), Handbook of geochemistry: Berlin (Springer-Verlag).

Crocket, J.H. and Skippen, G.B., 1966. Radioactivation determination of palladium in basaltic and ultrabasic rocks: Geochim. Cosmochim. Acta, v. 30, p. 129-141.

Crocket, J.H. and Chyi, L., 1972. Abundances of Pd, Ir, Os and $\mathrm{Au}$ in an alpine ultramafic pluton: Int. Geol. Congr. Proc., 24th, Sect. 10, p. 202-209.

Crocket, J.H., Keays, R.R., and Hsieh, S., 1968. Determination of some precious metals by neutron activation analysis: J. Radio-anal. Chem., v. 1, p. 487-507.

Gottfried, D. and Greenland, L.P., 1972. Variation of iridium and gold in oceanic and continental basalts: Int. Geol. Congr. Proc., 24th, Sect. 10, p. 135-144. 
Gottfried, D., Rowe, J.J., and Tilling, R.I., 1972. Distribution of gold in igneous rocks: U.S. Geol. Surv. Prof. Paper 727.
Greenland, L.P., Gottfried, D., and Tilling, R.I., 1974. Iridium in some calcic and calc-alkalic batholithic rocks of the western United States: Chem. Geol., v. 14, p. 117-122. 